\title{
EFEKTIVITAS PEMBELAJARAN STEREOKIMIA BERBASIS VISUALISASI 3D MOLEKUL UNTUK MENINGKATKAN KEMAMPUAN SPASIAL
}

\author{
Marina Setyarini' ${ }^{1}$ Liliasari $^{2}$, Asep Kadarohman ${ }^{2}$, dan Muhamad A. Martoprawiro ${ }^{3}$, \\ ${ }^{1)}$ PMIPA FKIP Universitas Lampung; ${ }^{2}$ Sekolah Pascasarjana UPI; ${ }^{3}$ Departemen Kimia-ITB \\ email: marina_setyorini@yahoo.com
}

\begin{abstract}
Abstrak: Penelitian ini bertujuan menyelidiki keefektifan program pembelajaran stereokimia berbasis visualisasi 3D molekul menggunakan salah satu chemical drawing software berbasis open source, yakni Avogadro dan animasi kekiralan melalui komputer untuk meningkatkan kemampuan spasial mahasiswa calon guru. Studi menggunakan quasi experimental control group pretest-posttest design. Instrumen penelitian terdiri atas 25 soal pilihan ganda disertai alasan yang disusun berdasarkan indikator tiga dimensi utama kemampuan spasial. Subjek penelitian terdiri atas kelas kontrol dan kelas eksperimen, masingmasing ada sebanyak 30 mahasiswa. Teknik pengumpulan data dilakukan dengan tes, sedang analisis data dilakukan dengan teknik statistik dengan bantuan SPSS versi 17. Hasil penelitian menunjukkan bahwa rata-rata skor post test kemampuan spasial kelompok mahasiswa dengan pembelajaran stereokimia berbasis visualisasi 3D molekul secara signifikan lebih tinggi dibandingkan kelompok mahasiswa yang media pembelajarannya menggunakan molymod. Keefektifan program ditunjukkan oleh peningkatan $\mathrm{N}$-gain dalam kategori sedang dan efek size (d) dalam kategori tinggi untuk ketiga dimensi utama kemampuan spasial.
\end{abstract}

Kata kunci: stereokimia, visualisasi 3D, kemampuan spasial, software open-source

\section{THE EFFECTIVENESS OF STEREOCHEMISTRY BASED ON 3D VISUALIZATION OF MOLECULES IN IMPROVING SPATIAL ABILITY}

\begin{abstract}
The purpose of this study is to investigate the effectiveness of stereochemistry learning programs based on 3D visualization of molecules using open source chemical drawing software, Avogadro, and animation of chirality to improve spatial ability of prospective teachers. This study used a quasiexperimental control group pre test-post test design. The research instrument consisted of 25 multiple choice questions along with the reasons elaboration, composed based on three major indicator dimensions of spatial ability. The research was conducted at a LPTK in Lampung Province, in the first semester of Academic Year 2014/2015. The subjects consisted of control class and experimental class, each of which consisted of 30 students. The results showed that the average post test score of spatial ability of students learning stereochemistry based on 3D visualization of molecules was significantly higher than those of the group of students learning using molymod media. The effectiveness of the program was shown by the increase in $\mathrm{N}$-gain in the medium category and effect size $(d)$ in high category for the three main dimensions of spatial ability.
\end{abstract}

Key words: stereochemistry, 3D visualization, spatial ability, open-source software

\section{PENDAHULUAN}

Kimia organik merupakan salah satu cabang ilmu kimia yang berpijak pada premis tunggal, bahwa "perilaku kimia ditentukan oleh struktur molekul" Molekul digambarkan dalam struktur 3D. Hubungan penataan atom-atom dalam ruang 3D dan sifat-sifat yang diakibatkannya, secara khusus dibahas pada topik stereokimia. Ada tiga aspek kajian dalam pembahasan topik stereokimia, yaitu isomeri geometri, konformasi, dan kiralitas (Morrison\& Boyd, 2002).
Banyak hasil studi melaporkan bahwa stereokimia merupakan salah satu topik yang sulit dipelajari. Beberapa faktor yang teridentifikasi sebagai penyebab kesulitan di antaranya karena benak seseorang perlu mengimajinasikan antara struktur 3D suatu molekul dengan gambar yang dicetak dalam 2D (Abraham, Varghese \& Tang (2010), kurangnya kemampuan mengintegrasikan antara definisi dan aturan-aturan, kurangnya penguasaan teknik penempatan pengamat, ren- 
dahnya kesadaran struktur spasial (Boukhechem, Dumon, \& Zoukri (2011). Hal ini dapat dipahami, karena ketika mempelajari ketiga aspek stereokimia, benak seseorang dituntut secara aktif mengimajinasikan tatanan ruang atom-atom atau gugus dalam sebuah molekul. Di saat mempelajari konformasi, menuntut imajinasi penataan dalam ruang yang berbeda-beda akibat rotasi gugus mengelilingi ikatan $\sigma$. Di saat mempelajari isomeri geometri atau isomer cistrans, menuntut imajinasi penataan dalam ruang yang berbeda-beda akibat ketegaran atau kekakuan ikatan dalam molekul. Kekiralan menuntut imajinasi penataan dalam ruang yang berbeda-beda merujuk pada molekulmolekul yang bersifat tidak dapat dihimpitkan dengan molekul bayangan cerminnya (Wade, 2006). Kemampuan seseorang memahami struktur 3D molekul dan secara mental mengimajinasikan prilakunya, dikenal sebagai kemampuan spasial (Lohman, 1979 dalam Harle \& Town, 2011; Pribyl \& Bodner, 1987; Carrol, 1993).

Lohman (Harle \& Town, 2011) mendefinisikan kemampuan spasial sebagai: "Kemampuan untuk menghasilkan, menyimpan, dan memanipulasi gambaran visual yang abstrak". Pada tingkat yang paling dasar, pemikiran spasial membutuhkan kemampuan untuk mengode, mengingat, mengubah, dan mencocokkan rangsangan spasial. Hasil studi meta analisis Lohman, menetapkan tiga faktor utama yang diidentifikasi sebagai dimensi utama kemampuan spasial, faktor-faktor ini muncul secara terus menerus dalam reanalisis. Tiga faktor utama tersebut yakni (i) hubungan spasial, (ii) orientasi spasial, dan (iii) visualisasi spasial. Faktor hubungan spasial meliputi tugastugas yang memerlukan rotasi mental dari suatu obyek baik pada bidang (2-D) atau keluar bidang (3-D). Orientasi spasial, meliputi kemampuan untuk membayangkan bagaimana sebuah objek atau array akan terlihat dari perspektif yang berbeda dengan reorientasi pengamat. Visualisasi spasial, faktor ini terdiri atas tugas-tugas yang memiliki komponen spasial-figural seperti gerakan atau perpindahan bagian dari gambar, merupakan tugas yang lebih kompleks daripada hubungan spasial maupun tugas-tugas orientasi spasial.

Kelemahan dalam kemampuan spasial individu, diduga kuat sebagai faktor utama yang menyebabkan stereokimia dianggap sebagai topik sulit dalam kajian kimia organik. Beberapa hasil penelitian menunjukkan bahwa perbedaan individu dalam penalaran spasial merupakan faktor utama yang berkontribusi bahkan memprediksi keberhasilan dalam perkuliahan kimia organik (Prybil \& Bodner, 1987; Stieû, et al, 2012). Peneliti lain menyatakan bahwa mahasiswa berkemampuan spasial tinggi pada matakuliah kimia umum, secara signifikan lebih unggul pada pertanyaan ujian geometri molekul dan struktur kristal dibandingkan mahasiswa berkemampuan spasial rendah (Carter, Larussa, \& Bodner, 1987). Selanjutnya, kemampuan spasial diakui berperan penting untuk keberhasilan dalam banyak pekerjaan, maupun peran prediktif dalam pilihan karir bidang utama STEM (science, tecnology, engineering, and mathematics) (Sorby, 2009). Namun demikian, meskipun keberhasilan dalam STEM dan disiplin lainnya, secara spesifik terkait erat kemampuan spasial, pendidik sering gagal mengembangkan kemampuan spasial siswa (Harle \& Towns, 2011).

Dalam kurikulum satu LPTK di Provinsi Lampung, topik stereokimia merupakan topik awal yang dibahas dalam perkuliahan Kimia Organik Lanjut. Suatu mata kuliah wajib yang ditawarkan pada semester 5 , berbobot 2sks. Pemahaman pada topik stereokimia menjadi dasar pemahaman pada topik-topik selanjutnya yang membahas mekanisme reaksi. Selama ini perkuliahan dalam topik stereokimia disajikan dengan media ball and stick yang didemonstrasikan dosen, serta model molekul buatan yang wajib dibuat oleh setiap mahasiswa calon guru untuk mempermudah pembelajaran. Namun media statis ini kurang optimal, mahasiswa calon guru masih mengalami kesulitan menafsirkan notasi representasi, serta pengubahan antar representasi.

Selain model fisik tradisional ball and stick yang bersifat statis, visualisasi dan program pemodelan molekul secara komputerisasi, saat ini tersedia dan dapat diakses melalui situs-situs internet secara open sources. Program tersebut dipromosikan lebih unggul dibandingkan pengajaran struktur molekul menggunakan rumus garis maupun menggunakan model fisik. Program komputer bersifat dinamis, dapat menampilkan struktur molekul di layar menjadi lebih "terlihat" dan "berperilaku" seperti "molekul nyata" (Hahre, Nelson \& Shusterman, 1998). Dampak pembelajaran menggunakan program komputer pun telah banyak dilaporkan peneliti diantaranya dapat membantu siswa mengatasi kesulitan memahamistruktur dan eleman simetri molekul kompleks (Tuvi-Arad \& Gorsky, 2007), alat bantu 
efektif untuk pengajaran stereokimia (Abraham, et al., 2010), meningkatkan skor post test secara signifikan pada topik terkait sudut ikatan, sifatsifat 3D molekul seperti kiralitas dan konformasi (Springer, 2014).

Meskipun kemampuan spasial individu telah teridentifikasi sebagai faktor utama yang menyebabkan stereokimia dianggap sebagai topik sulit, sejauh ini belum banyak studi yang melaporkan program pembelajaran yang berupaya melatihkan kemampuan spasial. Hal ini penting, mengingat konsep stereokimia bersifat abstrak, pada level mikroskopik, serta membutuhkan pemahaman spasial yang kompleks (Gilbert, 2005).

Dalam artikel ini akan dipaparkan implementasi program pembelajaran stereokimia menggunakan aplikasi structure drawing software bersifat open source, Avogadro, yang dapat didownload melalui situs internet http://download. cnet.com/windows/geoff-hutchison/, untuk memvisualisasikan struktur molekul 3D yang bersifat interaktif dan dinamis. Pengguna dapat mengubah-ubah tampilan molekul dengan berbagai jenis representasi, merotasikannya secara mudah melalui mouse sehingga relevan untuk membelajarkan konsep konformer dan isomeri geometri.Sementara konsep-konsep kekiralan, divisualisasikan melalui program animasi yang dirancang selaras dengan indikator pencapaian konsep kekiralan dan indikator ketiga dimensi utama kemampuan spasial.

\section{METODE}

Studi menggunakan quasi experimental control group pretest-posttest design. Studi dilaksanakan di Program Studi Pendidikan Kimia Jurusan Pendidikan MIPA di sebuah LPTK di Provinsi Lampung, semester ganjil tahun Akademik 2014/2015. Studi dilakukan terhadap 60 mahasiswa calon guru semester 5, yang mengontrak perkuliahan Kimia Organik Lanjut, terdiri 2 kelas, terdiri dari kelas kontrol dan eksperimen, masing-masing ada sebanyak 30 orang. Penentuan kelas kontrol dan eksperimen dilakukan secara undi. Pada kelas eksperimen diberikan tutorial praktikum, selama2 pertemuan@120 menit. Tutorial praktikum berupa pengenalan software visualisasi 3D menggunakan Panduan Tutorial yang tervalidasi oleh pakar komputasi kimia. Implementasi program pembelajaran stereokimia berbasis visualisasi 3D dilaksanakan sebanyak 4 pertemuan@2x50menit.

Instrumen tes berupa tes kemampuan spasial yang terintegrasi dengan penguasaan konsep stereokimia sebanyak 25 soal, berbentuk pilihan berganda disertai alasan. Skor maksimum untuk tiap soal adalah 3, masing-masing soal diberi skor 1 untuk pilihan pada opsi jawaban yang tepat, dan skor maksimum $=2$ untuk jawaban alasan.

Untuk mengetahui peningkatan kemampuan spasial antara sebelum dan sesudah pembelajaran ditunjukkan oleh gain ternormalisasi, $<\mathrm{g}>$, dihitung dengan rumus yang dikembangkan oleh Hake (2002): Interpretasi nilai gain ternormalisasi yakni, tinggi bila nilai $<\mathrm{g}>\geq 0,7$; sedang bila 0,7 $>(<\mathrm{g}>) \geq 0,3$; dan rendah bila $<\mathrm{g}><0,3$.

Efektivitas program diukur dengan effect size (d) dihitung dengan mengambil perbedaan dua nilai rata-rata kelompok eksperimen $\left(\mathrm{M}_{\mathrm{A}}\right)$ dan kelas kontrol $\left(\mathrm{M}_{\mathrm{B}}\right)$ dibagi dengan sebaran rata-rata nilai siswa $\left(\mathrm{SD}_{\text {pooled }}\right)$ yaitu:

$$
\text { Effect size }(d)=\frac{\mathrm{M}_{\mathrm{A}-} \mathrm{M}_{\mathrm{B}}}{\mathrm{SD}_{\text {pooled }}}
$$

Harga koefisien dampak $(d)$ diinterpretsikan menggunakan kriteria Cohen (1969dalam Coe, 2002), yakni berkriteria tinggi bila: $0,8 \leq(d)<$ 2,0; sedang bila $0,2 \leq(d)<0,8$; dan kecil bila 0,0 $\leq(d)<0,2$.

Uji statistik menggunakan SPSS versi 17. Analisis data dilakukan melalui uji-t (independent sample $t$ test) bagi kelompok data berdistribusi normal. Bagi kelompok data yang tidak berdistribusi normal, analisis satistik menggunakan uji statistik nonparametrik, Mann-Whitney U. Uji statistik dilakukan pada taraf signifikansi, $\alpha=0,05$.

\section{HASIL DAN PEMBAHASAN \\ Hasil Analisis Perbedaan Skor Pre-test, Post Test, dan N-gain Kemampuan Spasial}

Hasil analisis data perbedaan rata-rata skor pretes dan postest kemampuan spasial antara kelas kontrol yakni, kelompok mahasiswa yang diberi pembelajaran stereokimia secara konvensional menggunakan model molekul molymod $(\mathrm{N}=30)$, dan kelompok mahasiswa yang diberi pembelajaran stereokimia menggunakan visualisasi molekul 3Dmelalui chemical drawing software Avogadro dan animasi kekiralan $(\mathrm{N}=30)$, disajikan pada Tabel 1. 
Tabel 1. Uji Perbedaan Rata-Rata Skor Pretest, Postest dan N-Gain Kemampuan Spasial antara Kelas Kontrol dan Eksperimen

\begin{tabular}{clll}
\hline $\begin{array}{c}\text { Rerata } \\
\text { skor }\end{array}$ & \multicolumn{1}{c}{ Uji statistik } & $\begin{array}{c}\text { Signifi- } \\
\text { kansi }(p)\end{array}$ & \multicolumn{1}{c}{ Keterangan } \\
\hline Pretes & $\begin{array}{l}\text { Uji nonparametrik, Mann- } \\
\text { Whitney-U }\end{array}$ & $\begin{array}{l}0,625 \\
(\mathrm{p}>0,05)\end{array}$ & $\begin{array}{l}\text { Tidak ada perbedaan rata-rata yang } \\
\text { signifikan pada kelompok kontrol dan } \\
\text { eksperimen }\end{array}$ \\
Postes & $\begin{array}{l}\text { Uji t, (uji independent } \\
\text { sample t test), satu pihak }\end{array}$ & 0,000 & $\begin{array}{l}\text { Rata-rata skor post-test kelompok } \\
\text { eksperimen secara signifikan lebih tinggi } \\
\text { daripada kelas kontrol }\end{array}$ \\
N-gain & $\begin{array}{l}\text { Uji t, (ujiindependent } \\
\text { sample t test), satu pihak }\end{array}$ & 0,000 & $\begin{array}{l}\text { Rata-rata skor N-gain kelompok } \\
\text { eksperimen secara signifikan lebih tinggi } \\
\text { daripada kelas kontrol }\end{array}$ \\
\hline
\end{tabular}

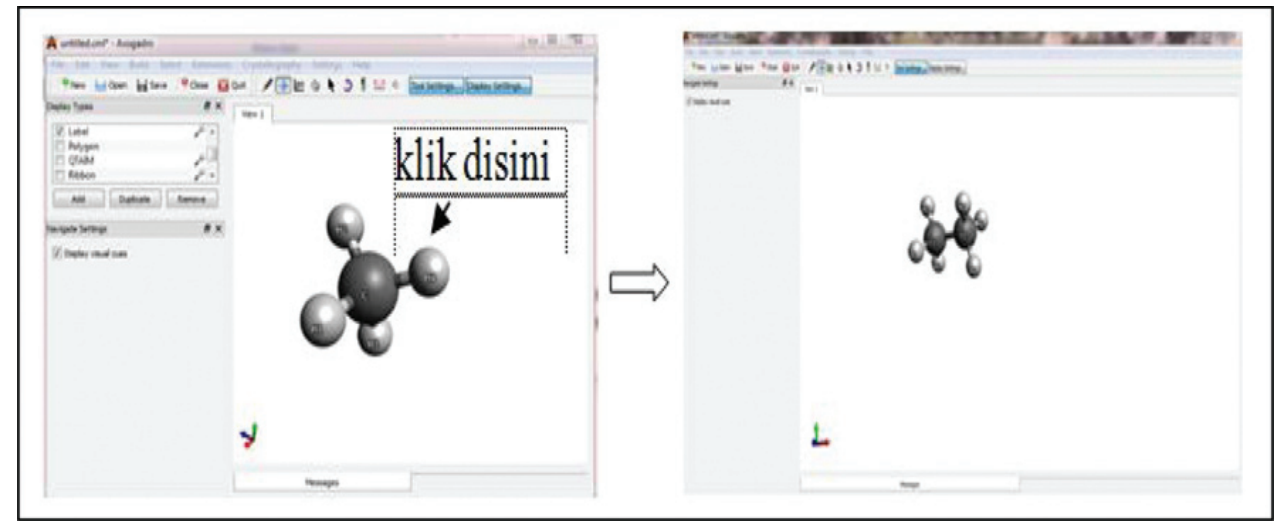

Gambar 1. Tampilan Software Avogadro

Berdasarkan data pada Tabel 1 diperoleh informasi bahwa berdasarkan analisis statistik, secara signifikan tidak terdapat perbedaan rata-rata skor pretes antara dua kelompok mahasiswayang berasal dari kelas kontrol dan eksperimen. Hasil uji ini memberikan kesimpulan bahwa sebelum intervensi, kemampuan spasial mahasiswa calon guru pada kedua kelompok mahasiswa sama. Pada uji perbedaan rata-rata skor post-test, satu pihak terhadap kedua kelompok data, diperoleh nilai $\mathrm{p}$ $=0,000,(\mathrm{p}<0,05)$.

Setelah dibandingkan dengan rumusan hipotesis, disimpulkan bahwa kelompok mahasiswa calon guru yang diberi pembelajaran menggunakan visualisasi 3D molekul dengan software Avogadro dan animasi kekiralan, secara signifikan, memiliki kemampuan spasial lebih tinggi dibandingkan kelompok mahasiswa calon guru yang mendapatkan pembelajaran secara konvensional. Pada N-gain, hasil uji perbedaan rata-rata satu pihak terhadap kedua kelompok data diperoleh nilai $\mathrm{p}=0,000,(\mathrm{p}<0,05)$.

Setelah dibandingkan dengan rumusan hipotesis, hasil uji ini menunjukkan bahwa peningkatan skor pretest dan posttest pada test kemampuan spasial antara kelompok mahasiswa calon guru yang diberi pembelajaran menggunakan visualisasi 3D molekul melalui software Avogadro dan animasi kekiralan, secara signifikan lebih tinggi daripada kelompok mahasiswa yang diberi pembelajaran stereokimia secara konvensional. Hasil di atas menunjukkan bahwa dampak pembelajaran menggunakan program komputer secara signifikan dapat meningkatkan kemampuan spasial. Hal ini dapat dipahami, karena melalui visualisasi menggunakan software Avogadro (Gambar 1), masing-masing mahasiswa calon guru memperoleh pengalaman "melihat secara nyata" penataan atom-atom dalam ruang secara akurat.

Selain itu, software juga dilengkapi dengan icon-icon yang membelajarkan bahwa molekul bersifat dinamis. Mahasiswa sebagai pengguna dapat mengoperasikan rotasi molekul melalui sumbu.Dengan software ini, pengguna dapat memvisualisasikan gambar molekul 3D dengan mengklikicon $y$ yang digunakan untuk menggambar, saat icon diklik, akan tampil draw setting, guna pengaturan gambar, diantaranya menu 
pemilihan jenis atom, pemilihan jenis ikatan, dan penambahan atom secara otomatis. Untuk merotasikan molekul pada layar, tersedia icon icon ini sangat membantu mahasiswa melatihkan salah satu dimesnsi utama kemampuan spasial, hubungan spasial.

Software visualisasi molekul Avogadro yang dilengkapi fasilitas merotasikan molekul secara interaktif, juga berpeluang mengaktifkan sisi aktif visuospasial sketchpath, suatu tempat bagian otak yang bertanggung jawab menyimpan informasi visual dan spasial dalam sistem kerja working memory. Proses kognisi ini sejalan perspektif psikologi kognitif yang mengungkapkan bahwa rangsangan visual akan mengaktifkan komponen memori kerja, sketsa visuo-spatial (Matlin, 2009). Komponen ini bertanggungjawab memproses informasi visual dan spasial. Informasi visual yang masuk ke dalam memori kerja, akan diseleksi. Informasi berkmaknaakandikode menjadi bagian dari sistem pengetahuan yang disimpan dalam long-term memory (Matlin, 2009).

\section{Efektivitas Program Pembelajaran}

Hasil studi meta-analisis Lohman (Harle $\&$ Towns, 2011) menetapkan ada tiga faktor penentu yang diidentifikasi sebagai dimensi utama kemampuan spasial. Tiga faktor utama tersebut yakni (i) hubungan spasial, (ii) orientasi spasial, dan (iii) visualisasi spasial.Hasil skor rata-rata $\mathrm{N}$-gain untuk mengetahui peningkatan ketiga dimensi kemampuan spasial antara kelompok mahasiswa yang diberi pembelajaran dengan visualisasi 3D dengan kelompok mahasiswa yang diberi pembelajaran menggunakan molymod sebagai media, disajikan pada Gambar 2.

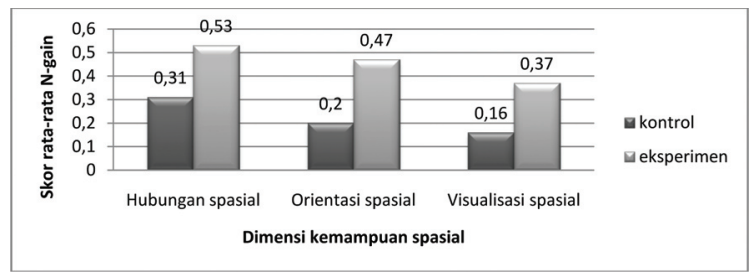

Gambar 2. Profil Skor Rata-rata n-gain pada ketiga Dimensi Kemampuan Spasial antara kelompok mahasiswa dalam kelas kontrol dan eksperimen

Diperoleh informasi bahwa skor rata-rata $\mathrm{N}$-gain pada ketiga dimensi utama kemampuan spasial yakni hubungan spasial, orientasi spasial, dan visualisasi spasial untuk kelompok mahasiswa dalam kelas kontrol berada pada kriteria rendah, sementara skor rata-rata $\mathrm{N}$-gain pada ketiga dimensi utama kemampuan spasial kelompok mahasiswa dalam kelas eksperimen berkriteria sedang. Hasil studi menunjukkan bahwa dari ketiga dimensi utama kemampuan spasial, baik kelas yang diberi pembelajaran dengan menggunakan visualisasi 3D melalui software Avogadro dan animasi kekiralan, maupun kelas yang diberi pembelajaran dengan menggunakan model molymod, mengalami peningkatan yang paling tinggi pada dimensi kemampuan spasial pada hubungan spasial, dan peningkatan paling kecil pada dimensi visualisasi spasial. Fakta ini dapat dipahami karena tugas-tugas yang diukur pada dimensi hubungan spasial terkait rotasi dan refleksi.

Tabel 2. Hubungan antara Indikator Kemampuan Spasial pada Dimensi Utama Hubungan Spasial dan Nomor Soal Tes

\begin{tabular}{lll}
\hline $\begin{array}{l}\text { Subtopik } \\
\text { Stereokimia }\end{array}$ & Indikator Dimensi Utama Hubungan Spasial & $\begin{array}{l}\text { Nomor } \\
\text { soal }\end{array}$ \\
\hline $\begin{array}{l}\text { Isomeri } \\
\text { Geometri }\end{array}$ & $\begin{array}{l}\text { Mampu mengindentifikasi secara tepat struktur-struktur molekul 3D } \\
\text { yang divisualisasikan sebagai pasangan isomer geometri pada alkena } \\
\text { atau sikloalkana diantara visualisasi molekul 3D lain yang terhubung } \\
\text { sebagai hasil proses rotasi terhadap sumbu tertentu. }\end{array}$ & 1,2 \\
Konformasi & $\begin{array}{l}\text { Mampu memutuskan struktur Proyeksi Newman secara tepat setelah } \\
\text { gugus/atom dari struktur molekul 3D yang divisualisasikan berotasi } \\
\text { terhadap sumbu ikatan dengan sudut tertentu. }\end{array}$ & 9,10 \\
& $\begin{array}{l}\text { Mampu memutuskan struktur konformasi sikloheksana tersubstitusi } \\
\text { antara sebelum dan sesudahflip over secara tepat. }\end{array}$ & 11,12 \\
$\begin{array}{l}\text { Mampu memutuskan secara tepat struktur molekul 3D yang bersifat } \\
\text { kiral dengan mengenali karakteristiknya di antara molekul lain yang } \\
\text { bersifat akiral. }\end{array}$ & 15,16 \\
\hline
\end{tabular}


Tugas ini lebih mudah, karena tidak terlalu kompleks dibandingkan tugas-tugas yang diukur dalam dimensi visualisasi spasial. Hasil ini mendukung teori yang dikemukakan Lohman (Harle \& Towns, 2011)yang menyatakan bahwa dimensi hubungan spasial terdiri dari tugas-tugas yang memerlukan rotasi mental dari suatu obyek baik pada bidang (2-D) atau keluar bidang (3-D). Dimensi orientasi spasial meliputi kemampuan untuk membayangkan bagaimana sebuah objek atau array akan terlihat dari perspektif yang berbeda dengan reorientasi pengamat. Dimensi visualisasi spasial terdiri tugas-tugas yang memiliki komponen spasial-figural seperti gerakan atau perpindahan bagian dari gambar, dan merupakan tugas yang lebih kompleks daripada tugas hubungan spasial atau tugas orientasi spasial.

\section{(a) Profil Kemampuan Spasial Mahasiswa Pada Dimensi Utama Hubungan Spasial}

Ada 8 soal test ditujukan untuk pengukuran kemampuan spasial pada dimensi utama hubungan spasial. Pada Tabel 2 dipaparkan hubungan antara subtopik stereokimia dengan indikator dimensi hubungan spasial dan nomor soalpada instrumen test kemampuan spasial.

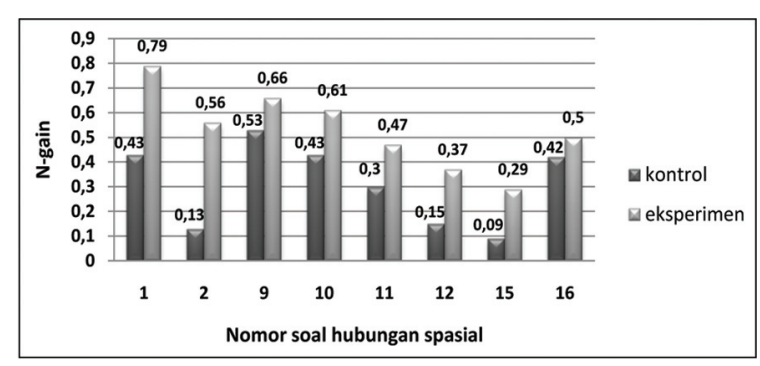

Gambar 3. Profil Skor Rata-rata N-gain pada Dimensi Hubungan Spasial antara

Kelompok Mahasiswa dalam Kelas Kontrol dan Eksperimen

Profil rata-rata skor N-gain kedua kelompok mahasiswa untuk 8 soal yang diujikan, disajikan pada Gambar 3. Berdasarkan profil tersebut diperoleh informasi bahwa rata-rata skor N-gain pada kelompok mahasiswa yang pembelajaran stereokimianya berbasis visualisasi $3 \mathrm{D}$, terdapat satu nomor (soal no. 1) berkriteria tinggi, dan 6 soal berkriteria sedang, dan 1 soal, yakni soal no 15, berkriteria rendah. Pada kelompok mahasiswa yang pembelajarnnya menggunakan molymod, terdapat 4 buah soal dengan skor rata-rata $\mathrm{N}$ gain berkriteria sedang dan terdapat 4 soal lain berkriteria rendah. Informasi lain yang diperoleh dari grafik yang disajikan, soal no 1 yaitu pada subtopik isomeri geometri berada pada kriteria tinggi, dan yang paling rendah ada pada soal no 15 pada subtopik kekiralan.

Item tes no 1 dan item no 15 disajikan pada Gambar 3. Penjelasan yang dapat dikemukakan untuk menjelaskan alasan bahwa pada soal nomor 1 (Gb.3a), skor rata-rata $\mathrm{N}$-gain kelompok mahasiswa eksperimen berkriteria tinggi untuk dimensi hubungan spasial adalah bahwa dalam pembelajaran, mahasiswa pada kelompok ini sudah mengenal operasi software Avogadro sejak tutorial praktikum dibandingkan dengan kelompok kontrol.


Gambar 4. (a) Item Soal Nomor 1; (b) Item Soal Nomor 15

Mahasiwa dalam kelompok ekeperimen sudah terlatih membayangkan dalam benak, kedudukan atom-atom antara sebelum dan sesudah operasi rotasi.Dapat dipahami karena melalui software Avogadro, operasi rotasi mudah dijalankan melalui mouse dan interaktif.Faktor lain yang diduga berpengaruh dalam kemampuan spasial mahasiswa pada dimensi hubungan spasial, adalah struktur molekul. Struktur molekul pada soal no 1 (Gb4a), terkait keisomeran geometri, merupakan 
Tabel 3. Hubungan antara Indikator Kemampuan Spasial pada Dimensi Utama Orientasi Spasial dengan Nomor Soal Tes.

\begin{tabular}{lll}
\hline $\begin{array}{l}\text { Subtopik } \\
\text { Stereokimia }\end{array}$ & Indikator Dimensi Utama Orientasi Spasial & $\begin{array}{l}\text { Nomor } \\
\text { Soal }\end{array}$ \\
\hline $\begin{array}{l}\text { Isomeri } \\
\text { Geometri }\end{array}$ & $\begin{array}{l}\text { Mampu mengidentifikasi secara tepat tatanan atau orientasi atom- } \\
\text { atom dalam suatu struktur isomer geometri yang divisualisasikan } \\
\text { dengan molekul 3D jika namanya diketahui. }\end{array}$ & 3,4 \\
Konformasi & $\begin{array}{l}\text { Mampu mengidentifikasi secara tepat tatanan atau orientasi atom-atom } \\
\text { dalam proyeksi Newman bagi suatu struktur konformer yang } \\
\text { Molekul }\end{array}$ & 7,8 \\
Alifatik & $\begin{array}{l}\text { divisualisasikan secara 3D } \\
\text { Konformasi } \\
\text { Molekul Siklik }\end{array}$ & $\begin{array}{l}\text { pada struktur konformer sikloheksana tersubstitusi yang terhubung } \\
\text { sebagai pasangan isomer geometri. }\end{array}$ \\
Kekiralan & $\begin{array}{l}\text { Mampu memutuskan secara tepat tatanan atau orientasi atom/gugus di } \\
\text { seputar atom karbon kiral, mampu menentukan arah perputaran gugus }\end{array}$ & 17 \\
& $\begin{array}{l}\text { sesuai prioritas atau konfigurasi mutlaknya dengan memberikan notasi } \\
\text { menurut aturan Chan-Ingold-Prelog. }\end{array}$ & \\
& $\begin{array}{l}\text { Mampu memutuskan secara tepat hubungan antar stereoisomer dalam } \\
\text { senyawa kiral siklik melalui identifikasi tatanan atau orientasi } \\
\text { atom/gugus di seputar atom C kiral. }\end{array}$ & 24 \\
& $\begin{array}{l}\text { Mampumemutuskan secara tepat tatanan atau orientasi atom/gugus } \\
\text { pada senyawa dissimetri selaras penempatan pengamat, penentuan arah } \\
\text { perputaran gugus sesuai prioritas atau konfigurasi mutlaknya dengan } \\
\text { pemberian notasi analog aturan Chan-Ingold-Prelog. }\end{array}$ & 25 \\
\hline
\end{tabular}

molekul alkena yang berhibridisasi $s p^{2}$, berbentuk datar/planar, sementara molekul pada soal nomor 15 (Gb. 4b) berbentuk tetrahedral. Penataan atom-atom dalam struktur molekul alkena lebih sederhana dibandingkan penataan atom dalam struktur tetrahedral yang lebih kompleks.

Dalam hal ini, tampak bahwa mahasiswa dalam kelompok eksperimen maupun kontrol lebih mudah mengimajinasikan rotasi molekul sederhana daripada molekul-molekul kiral yang berbentuk lebih kompleks.Hasil ini mendukung kajian yang dilaporkan oleh Olimpo et al, (2014) bahwa kompleksitas struktur mempengaruhi kinerja mahasiswa dalam tugas-tugas rotasi pada Proyeksi Newman.

\section{Profil Kemampuan Spasial pada Dimensi Utama Orientasi Spasial}

Ada 9 soal tes ditujukan untuk pengukuran kemampuan spasial pada dimensi utama hubungan spasial. Pada Tabel 4 dipaparkan hubungan antara subtopik stereokimia dengan indikator dimensi orientasi spasial dan nomor soal pada instrumen test kemampuan spasial. Profil ratarata skor $\mathrm{N}$-gain kedua kelompok mahasiswa untuk 9 soal (Tabel 3) yang diujikan, disajikan pada Gambar 5.

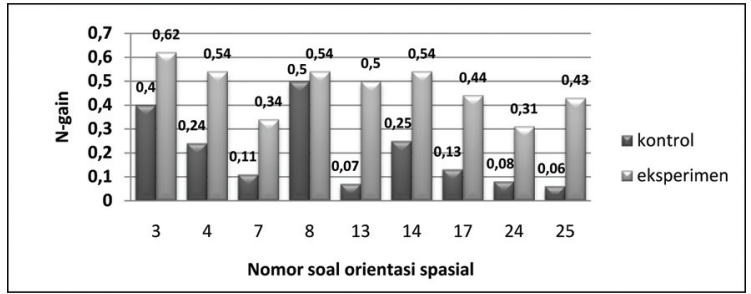

Gambar 5. Profil Skor Rata-rata N-gain pada Dimensi Orientasi Spasial antara Kelompok Mahasiswa dalam Kelas Kontrol dan Eksperimen

Berdasarkan profil tersebut diperoleh informasi bahwa rata-rata skor $\mathrm{N}$-gain pada kelompok mahasiswa yang pembelajaran stereokimianya berbasis visualisasi $3 \mathrm{D}$, berkriteria sedang pada ke-9 soal yang diujikan. Pada kelompok mahasiswa yang pembelajarannya menggunakan molymod, terdapat 2 buah soal (no.3, dan no.8) dengan skor rata-rata $\mathrm{N}$-gain berkriteria sedang dan terdapat 7 soal lain berkriteria rendah. Hasil ini menunjukkan bahwa kelompok mahasiswa yang pembelajarannya menggunakan visualisasi 3D dengan Avogadro pada topik konformasi dan isomeri geometri serta animasi pada topik kekiralan dapat meningkatkan kemampuan spasial mahasiswa calon guru pada dimensi orientasi spasial dengan rata-rata pada kriteria sedang. 
Berdasarkan Gambar 5, diperoleh informasi bahwa pada soal nomor 8, baik kelompok mahasiswa pada kelompok eksperimen maupun kelompok kontrol, rata-rata skor N-gain hampir sama. Artinya kedua kelompok mahasiswa baik yang pembelajarannya menggunakan visualisasi Avogadro maupun menggunakan molymod, mengalami peningkatan sama. Dapat dipahami, karena pada item tes ini indikator yang diukur adalah mampu mengidentifikasi secara tepat tatanan atau orientasi atom-atom dalam proyeksi Newman bagi suatu struktur konformer yang divisualisasikan secara 3D. Artinya untuk soal nomor 8 (Gambar6) melalui model molymod, mahasiswa pada kelompok kontrol mampu memahami tatanan atom suatu struktur, dengan baik.

\section{Profil Kemampuan Spasial Mahasiswa pada Dimensi Utama Visualisasi Spasial}

Ada 8 soal test ditujukan untuk pengukuran kemampuan spasial pada dimensi utama visualisasi spasial. Pada Tabel 4 dipaparkan hubungan antara subtopik stereokimia dengan indikator dimensi utama visualisasi spasial dan nomor soal pada instrumen test. Profil rata-rata skor N-gain kedua kelompok mahasiswa untuk 8 soal yang diujikan, disajikan pada Gambar 7. Berdasarkan profil tersebut diperoleh informasi bahwa ratarata skor $\mathrm{N}$-gain pada kelompok mahasiswa yang pembelajaran stereokimianya berbasis visualisasi $3 \mathrm{D}$, terdapat 6 soal berkriteria sedang, dan 2 soal berkriteria rendah, yakni soal nomor 18 dan 20 .

Pada kelompok mahasiswa yang pembelajarannya menggunakan molymod, terdapat 4

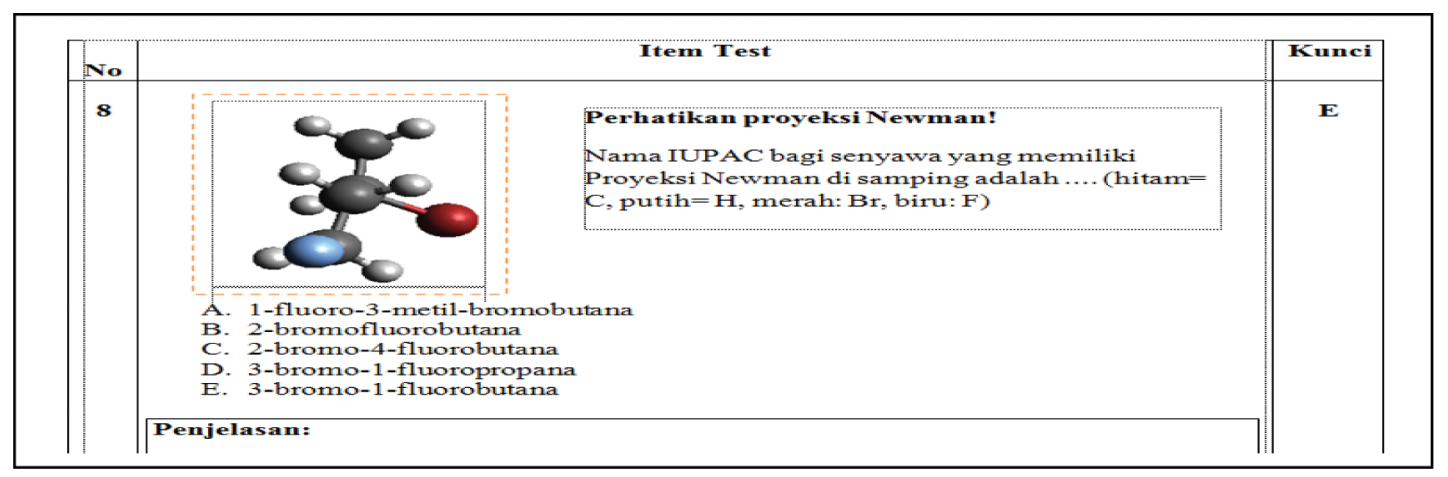

Gambar 6. Item Tes no. 8 pada Instrumen Tes Kemampuan Spasial pada Dimensi Utama Orientasi Spasial

Tabel 4. Hubungan antara Indikator Kemampuan Spasial pada Dimensi Utama Visualisasi Spasial dengan Nomor Soal Tes

\begin{tabular}{lll}
\hline $\begin{array}{l}\text { Subtopik } \\
\text { Stereokimia }\end{array}$ & Indikator Dimensi Utama Visualisasi Spasial & $\begin{array}{l}\text { Nomor } \\
\text { Soal }\end{array}$ \\
\hline $\begin{array}{l}\text { Isomeri } \\
\text { Geometri }\end{array}$ & $\begin{array}{l}\text { mampu mengidentifikasi secara tepat visualisasi bangun struktur } \\
\text { Kekiralan }\end{array}$ & $\begin{array}{l}\text { molekul bila notasi keisomeran geometrinya diketahui } \\
\text { mampu mengidentifikasi secara tepat visualisasi bangun struktur } \\
\text { molekul 3D kiral dengan notasi konfigurasi mutlak yang telah }\end{array}$ \\
& $\begin{array}{l}\text { ditentukan. } \\
\text { mampu menginterpretasikan secara tepat bangun struktur molekul kiral } \\
\text { dalam ruang 3D yang divisualisasikan melalui Proyeksi Fischer (2D) }\end{array}$ & 18,20 \\
& $\begin{array}{l}\text { serta interkonversi ke struktur dimensional atau sebaliknya. } \\
\text { mampu mengindentifikasi secara tepat hubungan antar stereoisomer }\end{array}$ & 21,22 \\
& $\begin{array}{l}\text { senyawa dengan 2 pusat kiral melalui visualisasi berbagai representasi } \\
\text { dan interkonversi struktur molekul 3D seperti dari Proyeksi Fischer }\end{array}$ & \\
& $\begin{array}{l}\text { (2D) ke struktur dimensional atau sebaliknya. } \\
\text { mampu mengindentifikasi secara tepat visualisasi berbagai representasi } \\
\text { dan interkonversi antar struktur molekul 3D kiral seperti dari Proyeksi }\end{array}$ & 23 \\
& $\begin{array}{l}\text { Newman ke rumus dimensional, Proyeksi Fischer (2D) ke proyeksi } \\
\text { Newman atau sebaliknya }\end{array}$ & \\
\hline
\end{tabular}


Tabel 5. Effect Size pada Ketiga Dimensi Utama Kemampuan Spasial antara Kelas Kontrol dan Eksperimen

\begin{tabular}{ccccccc}
\hline $\begin{array}{c}\text { Dimensi utama } \\
\text { kemampuan } \\
\text { spasial }\end{array}$ & $\begin{array}{c}\text { Mean } \\
\text { kelas } \\
\text { kontrol }\end{array}$ & $\begin{array}{c}\text { Mean kelas } \\
\text { eksperimen }\end{array}$ & $\begin{array}{c}S D \\
\text { kelas } \\
\text { kontrol }\end{array}$ & $\begin{array}{c}\text { SD kelas } \\
\text { eksperimen }\end{array}$ & $\begin{array}{c}\text { Efeect } \\
\text { Size } \\
(\boldsymbol{d})\end{array}$ & Interpretasi \\
\hline $\begin{array}{c}\text { Hubungan } \\
\text { Spasial }\end{array}$ & 5,47 & 9,50 & 3,702 & 4,64 & 0,97 & tinggi \\
$\begin{array}{c}\text { Orientasi } \\
\text { Spasial } \\
\text { Visualisasi } \\
\text { Spasial }\end{array}$ & 4,07 & 9,90 & 4,29 & 3,94 & 1,42 & tinggi \\
\hline
\end{tabular}

buah soal dengan skor rata-rata N-gain berkriteria sedang dan terdapat 4 soal lain berkriteria rendah. Informasi lain yang diperoleh dari grafik yang disajikan, soal nomor 18 yaitu pada subtopik kekiralan, pada kelas yang pembelajarannya secara konvensional, rata-rata skor N-Gain bernilai negatif.Artinya rata-rata skor post-test lebih rendah dibandingkan skor pre-test.



\section{Gambar 7. Profil Skor Rata-rata N-gain pada Dimensi Visualisasi Spasial antara Kelompok Mahasiswa dalam Kelas Kontrol dan Eksperimen}

Pada Tabel 5 ditunjukkan hasil perhitungan efek size pada ketiga dimensi utama kemampuan spasial untuk menunjukkan keefektifan program pembelajaran stereokimia berbasis visualisasi 3D molekul.

\section{Pembahasan}

Diperoleh informasi bahwa besarnya effect size pada ketiga dimensi kemampuan spasial yaitu hubungan spasial, orientasi spasial dan visualisasi spasial, menurut Cohen (1969) tergolong tinggi. Hal ini mengindikasikan bahwa pogram pembelajaran melalui penggunaan software visualisasi 3D molekul berbasis open-source sangat efektif dalam meningkatkan ketiga dimensi utama kemampuan spasial. Hasil ini mendukung beberapa peneliti yang menyatakan bahwa kemampuan spasial berkembang selama seumur hidup seseorang, dan bahwa intervensi dapat meningkatkan kemampuan spasial meskipun ada sebagian ahli tidak sependapat dan berpandangan bahwa kemampuan spasial bersifat kemampuan bawaan daripada keterampilan trainable (Harle \& Towns, (2011).

Hal ini dapat dipahami karena dalam kelas yang pembelajarannya melalui chemical drawing software, Avogadro, masing-masing mahasiswa terlibat secara aktif, terlatih menggambarkan berbagai struktur 3D molekul, selanjutnya secara interaktif melalui mouse, dapat merotasikannya secara dinamis, mengamati secara aktif perubahan posisi atom-atom, membandingkan tatanan atom secara jelas dalam ruang antara sebelum sesudah rotasi. Diyakini, melalui proses ini, rangsangan visual melalui komputer berupa struktur-struktur 3D molekul yang dinamis ini, mengaktifkan komponen memori kerja, sketsa visuo-spatial mahasiswa, dengan demikian dimensi hubungan spasial yang melibatkan operasi rotasi, ditingkatkan.

Melalui animasi kekiralan, mahasiswa juga dilatihkan untuk mengamati secara aktif proses refleksi struktur molekul kiral 3D, juga translasi dari satu representasi struktur molekul ke representasi lain, secara dinamis, proses ini membantu mahasiswa melatihkan dimensi hubungan spasial dan visualisasi spasial, melalui animasi kekiralan yang memvisualisasikan orientasi pasanganpasangan enansiomer $(\mathrm{R})$ dan $(\mathrm{S})$ yang dinamis, dimensi utama orientasi spasial dilatihkan. Hal ini tentu saja tidak terpenuhi bila dalam pembelajaran menggunakan model ball \& stick yang statis.

Selain itu, pentingnya peran media visualisasi dinyatakan dalam literatur dan hasil penelitian, di antaranya Rusman, Kurniawan, \& Riyana (2011) menyatakan bahwa visualisasi molekul melalui komputer membantu menyampaikan informasi guna memperoleh pengetahuan. Abraham et al, (2010), melaporkan bahwa kelompok mahasiswa yang diberi representasi molekul melalui 
komputer memperoleh skor lebih tinggi secara signifikan dari kelompok kontrol yang pembelajaran stereokimianya menggunakan model fisik ball and stick dan gambar 2D.

Springer (2014), mengklaim bahwa dengan sekedar melihat manipulasi-manipulasi secara tepat yang dilakukan dosen pada sebuah model komputer selama dua semester secara berturutturut pada perkuliahan kimia organik pada mahasiswa S1, meningkatkan skor post test secara signifikan pada topik terkait sudut ikatan, sifatsifat 3D molekul seperti kiralitas dan konformasi. Selain itu pembelajaran dengan media visualisasi menarik dan membantu mahasiswa memahami molekul yang bersifat abstrak, hal ini senada dengan Derlina \& Lia Afrianti Nst. (2016) yang melaporkan bahwa penerapan model pembelajaran inquiry training berbantuan media visual berupa video membuat pembelajaran menarik, membantu siswa pemahaman konsep yang bersifat abstrak.

Proses-proses ini dapat dijelaskan seturut perspektif psikologi kognitif yang mengungkapkan bahwa rangsangan visual mampu mengaktifkan komponen memori kerja, sketsa visuo-spatial (Baddeley, 2000 dalam Matlin, 2009). Informasi visual yang masuk ke dalam memori kerja, akan diseleksi. Informasi berkmakna selanjutnya dikode menjadi bagian dari sistem pengetahuan yang disimpan dalam long-term memory. Hasil penelitian menunjukkan bahwa level pengolahan informasi bermakna dan mendalam menyebabkan retensi bersifat permanen daripada jenis pengolahan yang dangkal (Matlin, 2009).

Pengalaman pembelajaran ini sekaligussebagaicontoh pengalaman langsung bagi mahasiswa calon guru kimia dalam mengupakan peningkatan kompetensi pedagogik agar mampu memanfaatkan teknologi informasi yang tersedia untuk kepentingan pembelajaran, meningkatkan kompetensi profesionalnya dalam menggunakan piranti lunak komputer untuk meningkatkan pembelajaran kimia di kelas (Permendiknas RI no. 16,2007 )

\section{SIMPULAN}

Dalam penelitian ini telah dilakukan implementasi program pembelajaran stereokimia berbasis visualisasi struktur 3D molekul menggunakan structure drawing software Avogadro yang bersifat open source dan animasi kekiralan melalui komputer. Hasil studi menunjukkan bahwa rata- rata skor post test kemampuan spasial kelompok mahasiswa dengan pembelajaran stereokimia berbasis visualisasi 3D molekul secara signifikan lebih tinggi dibandingkan kelompok mahasiswa yang media pembelajarannya menggunakan molymod. Keefektifan program ditunjukkan oleh peningkatan $\mathrm{N}$-gain dalam kategori sedang dan efek size $(d)$ dalam kategori tinggi pada ketiga dimensi utama kemampuan spasial.

\section{UCAPAN TERIMAKASIH}

Peneliti mengucapkan terimakasih pada DIKTI yang telah mendanai pendidikan dan penelitian, Ketua Jurusan PMIPA FKIP Unila atas izin sebagai tempat pelaksanaan penelitian, seluruh mahasiswa Prodi Kimia yang terlibat dalam penelitian, serta saudara Andrian Saputra, S.Pd. M.Si yang telah membantu peneliti demi kelancaran pelaksanaan penelitian ini.

\section{DAFTAR PUSTAKA}

Abraham, M., Varghese. V, \& Tang H. 2010. "Using Molekular Representation to aid Student understanding of stereomical concepts". Journal of Chemical Education.87, (12), 1425-1429.

Boukhechem, M. S., Dumon, A., \& Zoukri. M. 2011. "The acquisition of stereochemicalknowledge by Algerian student intending to teach physical sciences". Chemistry Education Research and Practice, 12, 331-343.

Carter, C. S., Larussa, M. A., \& Bodner, G. M. 1987." A study of two measures of spatial ability as predictors of success in different levels of general chemistry". Journal of Research in Science Teaching, 24, 645-657.

Carroll, J.B. 1993. Human Cognitive Abilities: A Survey of Factor-Analytic Studies. Cambridge, England: Cambridge University Press: pp 304-363.

Coe, R. 2002."It's the EffectSize, Stupid. What effect size and why it is Important". Paper presented at the British Educational Research Association annual conference, Exeter, 12-14 September. Retrieved from http://www.cem.org/attachments/ebe/ ESguide.pdf. 
Derlina \& Lia Afrianti Nst. 2016. "Efek Penggunaan Model Pembelajaran Inquiry Training Berbantuan Media Visual dan Kreativitas Terhadap Keterampilan Proses Sains Siswa", dalam Cakrawala Pendidikan, Jurnal Ilmiah Pendidikan XXXV (2), hlm 153-163.

Gilbert, J.K. 2005. Visualization in Science Education. Dordrecht, Netherlands: Springer.

Hahre, W.J., Nelson, J.E., \& Shusterman, A.J. 1998. The Molecular Modeling Workbook for Organic Chemistry. Irvine: Wavefunction, Inc.

Hake, R. R. 2002. "Relationship of Individual Student Normalized Learning Gains in Mechanics with Gender, High-School Physics, and Pretest Scores on Mathematics and Spatial Visualization". Retrieved from http://www.arxiv.org.

Harle, M. \& Towns, M. 2011. "A Review of Spatial Ability Literature, Its Connection to Chemistry, and Implications for Instruction".Journal of Chemical Education, 88 (3), 351-360.

Matlin, M.W. 2009. Cognitive Psychology. Seventh Edition. John Wiley \& Son (Asia), Inc.

Morrison, R.T. \& Boyd, R. N. 2002. Organic Chemistry. Sixth Edition. New Delhi: Prentice-Hall of India.

Olimpo, J.T, Kumi, B.C., Wroblewski, R., Dixon, B. L. 2014. "Examining the relationship between 2D diagrammatic conventions and Students' success on representational translation task in Organic Chemistry". Chemistry Education Research and Practice.16, 143-153.
Peraturan Menteri Pendidikan Nasional Republik Indonesia, No 16 Tahun 2007, Tentang Standar Kualifikasi Akademik dan Kompetensi Guru.

Pribyl, J. R.; Bodner, G. M. 1987. "Spatial Ability and Its Role in Organic Chemistry: A Study of Four Organic Courses". J. Res. Sci. Teach, 24, 229-240.

Rusman, Kurniawan, D., \& Riyana, C. 2011. Pembelajaran Berbasis Teknologi Informasi dan Komunikasi:Mengembangkan Profesionalitas Guru. Jakarta: Rajawali Pers.

Springer, M.T. 2014. "Improving Students' understanding of Molecular Structure through Broad-Based Use of Computer Models in the Undergraduate Organic Chemistry Lecture". Journal of Chemical Education, 91 (8), 1162-1168.

Stieff, M., Ryu, M., Dixon, B., Hegarty, M. 2012. "The Role of Spatial Ability and Strategy Preference for Spatial Ability for Spatial Problem Solving in Organic Chemistry". Journal of Chemical Education, 89, 854859

Sorby, S.A. 2009. "Educational Research in Developing 3-D Spatial Skill for Engineering Students". International Journal of Science Education, 31(3), 459-480.

Tuvi-Arad, I., \& Gorsky, P. 2007. "New visualization tools for learning molecular symmetry: a preliminary evaluation". Chemistry Education Research and Practice, 8, (1), 61-72.

Wade, L. G. Jr. 2006.Organic Chemistry $\left(6^{\text {th }}\right.$ Edition). Upper Saddle River, New Jersey: Pearson Prentice Hall

Avogadro for Windows, Retrieved from http:// download.cnet.com/windows/geoff-hutchison/ 